\title{
SISTEM PENDAFTARAN HOTSPOT ONLINE BERBASIS WEB MENGGUNAKAN MIKROTIK API, PHP, MYSQL PADA SMK PLUS NURUL HAKIM KEDIRI
}

\author{
(Web-Based Online Hotspot Registration System Using Mikrotik API, PHP, MySql at \\ Vocational Plus Nurul Hakim Kediri)
}

\author{
Yusran Said*, Andy Hidayat Jatmika, I Wayan Agus Arimbawa \\ Program Studi Teknik Informatika, Fakultas Teknik Universitas Mataram \\ J. Majapahit 62, Mataram, Lombok NTB, INDONESIA \\ Email: yusronsaid@gmail.com, [andy, arimbawa]@unram.ac.id
}

\begin{abstract}
Nowadays the use of internet access is a priority for everyone. One of the internet media that is often used today is a hotspot network. Hotspot use at vocational high school (SMK) Plus Nurul Hakim using Indiehome wifi router. By default, the hotspot security on this device uses a single password for all users connected to this hotspot network. This causes the security of the hotspot network is not safe, inefficient time and increases the workload of the Hotspot manager to change password at every change. Based on these problems, research is conducted that aims to create a web-based online hotspot registration system by using the PHP Programming Language, MikroTik PHP Class API, and MySQL Database. The results of this study are expected to be a solution to overcome the problem of hotspot service on vocational high school Plus Nurul Hakim Kediri. If using this hotspot registration system will help users register quickly.
\end{abstract}

Keywords words: System Register Hotspot, API Mikrotik, PHP, MysQl, Mikrotik.

*Penulis Korespondensi

\section{Pendahuluan}

Sekolah Menengah Kejuruan (SMK) Plus Nurul Hakim Kediri Lombok Barat NTB merupakan Sekolah yang berbasis pesantren. Dimana pada sekolah ini pemanfaatan jaringan komputer dan internet sangatlah penting dalam menunjang segala aktifitas yang berkaitan dengan pembelajaran, maupun administrasi sekolah sehingga akses ke jaringan internet sangatlah penting. Saat ini Sekolah Menengah Kejuruan (SMK) Plus Nurul Hakim Kediri Lombok Barat NTB memiliki 177 siswa yang terbagi atas tiga jurusan yaitu teknik otomotif, teknik komputer dan jaringan dan tata busana. Dimana sekolah ini memiliki tenaga pendidik yang terdiri dari 36 (tiga puluh enam) dan 4 (empat) orang tenaga administrasi.

Pada Sekolah Menengah Kejuruan (SMK) Plus Nurul Hakim ini akses ke internet yang digunakan yaitu jaringan wifi hotspot. Untuk memperoleh akses ke jaringan wifi hotspot bagi guru, staf karyawan, maupun siswa siswi maka dibutuhkan username dan password yang didapatkan secara manual dari pihak pengelola jaringan pada sekolah ini. Penggunaan jaringan wifi hotspot di sekolah ini sangat tidak efisien karna menggunakan single password.
Dalam penggunaan layanan internet dengan model seperti ini membuat proses penggunaan internet tidak efisien, pada dasarnya penggunaan fasilitas internet dapat dipantau dan dikelola, Bandwith upload, Bandwith download, Jumlah perngguna, hingga pemberian username dan password pada jaringan tersebut MIKROTIK adalah salah satu penyedia peralatan dan layanan tersebut yang dapa membantu dalam proses pengelolaan bandwith [1]. Application Programmable Interface (API) memungkinkan pengembang atau network administrator untuk merancang solusi perangkat lunak khusus yang dapat berkomunikasi dengan RouterOS untuk mengumpulkan informasi, menyesuaikan konfigurasi dan mengelola router. API pada dasarnya memberikan tampilan berbasis text erat mengikuti sintaks dari antarmuka baris perintah Command Line Interfaces (CLI). Hal tersebut dapat digunakan untuk membuat alat konfigurasi yang diterjemahkan atau khusus untuk membantu kemudahan penggunaan menjalankan dan mengelola router dengan RouterOS [2]. selain dengan API Mikrotik sistem yang akan di bangun dengan menerapkan pengoelolaan username dan password menggunakan MySQL merupakan sebuah open source 
relational database management system(RDBMS) dimana server ini memberikan layanan basis data SQL (Structured Query Language) yang sangat cepat, multithreaded, multi-pengguna, dan kuat[3]. Oleh karena itu, pada penelitian tugas akhir ini akan dilakukan penelitian tentang sitem pendaftaran pengguna layanan hotspot berbasis web menggunakan API Mikrotik yang di integerasikan dengan MYSQL untuk mengelola penggunaan jaringan pada SMK Plus Nurul Hakim Kediri.

\section{Tinjauan Pustaka}

Zuhar Musliyana melakukan penelitian tentang sistem pendaftaran hotspot online berbasis web pada (STMIK U'budiyah). Penelitian ini dilakukan agar pengguna bisa melakukan pendaftran secara mandiri lewat web sehingga akan memudahkan pengguna dalam proses pendaftaran [4].

Muhammad Mahfud Abdul Ghoni melakukan penelitian tentang perancangan manajemen user pada hotspot menggunakan mikrotik pada (dcinnamons). Penelitian ini dilakukan untuk memberikan akses internet kepada pelanggan yang sudah melakukan pendaftaran dan sistem ini juga akan menonaktifkan pelanggan yang telah habis masa aktifnya [5].

Bayu Hermawan melakukan penelitian tentang perancangan jaringan hotspot server berbasis mikrotik pada (Universitas Abulyatama). Penelitian ini dilakukan untuk memberikan akses jaringan hotspot kepada semua pengguna internet yang ada dilingkungan gedung kuliah Universitas Abdulyatama [6].

Penelitian lain dalam pengimplementasian pembuatan jaringan mikrotik hotspot baru yang dimaksudkan untuk mempermudah pengguna internet di SMK Asta Mitra Purwodadi dalam mengkases jaringan internet melalui jaringan hotspot[7].

Tjaja Budi Santoso merancang Sistem administrasi RADIUS server berbasis web untuk lebih mempermudah administrator dalam mengelola user jaringan komputer [8].

Arif Wicahyanto dalam penelitianya mengembangkan aplikasi berbasis web yang digunakan pengguna hotspot untuk melakukan pendaftaran dan pengelola hotspot untuk melakukan verifikasi [9].

Samsul Arifin dalam penelitianya mernacang sistem yang mampu memberikan kemudahan saat pendaftaran user serta layanan hotspot dan kemudahan lain bagi kepala laboratorium dan operator layanan hotspot dalam mengkonfirmasi serta menerima pengaduan terkait layanan internet[10].

Berdasarkan permasalahan yang diangkat, pada penelitian ini akan dibangun sistem berbasis website dalam mengelola proses pendafataran hotspot online berbasis web untuk mempermudah dalam proses asksespenggunaan layanan hotspot wifi.

\section{Metode Peneltian}

\subsection{Proses Diagram Alir Penelitian}

Dalam melakukan sebuah penelitian, dibutuhkan suatu perancangan penelitian agar penelitian dapat dikerjakan secara teratur. Adapun alur perancangan penelitian dalam mengerjakan sistem pendaftaran pengguna layanan hotspot online berbasis web menggunakan mikrotik API, PHP dan MySQL pada Sekolah Menengah Kejuruan (SMK) Plus Nurul Hakim Kediri Lombok Barat NTB.

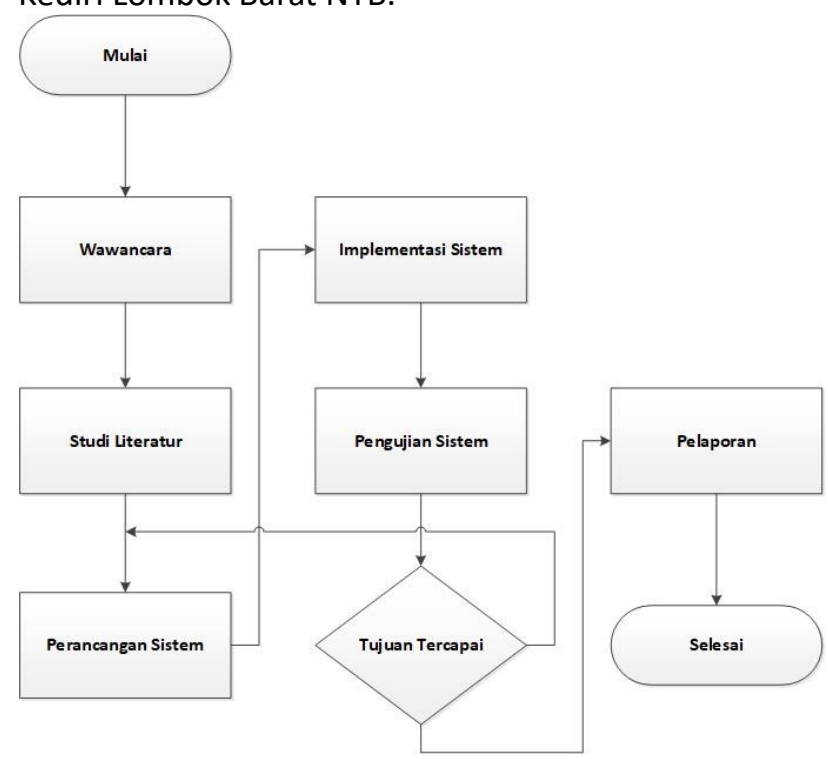

Gambar 1. Proses diagram alir penelitian

Pada tahap studi literatur dilakukan pengumpulan jurnal, artikel, makalah, maupun artikel dari situs internet yang berkaitan tentang metode dan permasalahan yang diangkat dalam penelitian tugas akhir ini.

Pada tahap perancangan sistem dilaksanakan perancangan sistem yang berkaitan tentang antar muka dan perancangan fungsi-fungsi dari sitem yang akan dibangun untuk melakukan pendaftaran akun oleh pengguna sesuai ketentuan yang telah ditetapkan.

Tahap implementasi sistem dan pengujian akan dilakukan pada program yang telah dibuat untuk 
mengetahui apakah program atau sistem yang telah dibuat berhasil atau tidak. Apabila program yang dibuat berhasil atau telah sesuai dengan tujuan dan rumusan masalah yang telah ditetapkan. Jika tujuan pembuatan sistem sudah tercapai maka akan dilanjutkan ke tahap pembuatan laporan. Dan apabila program yang dibuat tidak sesuai dengan tujuan dan rumusan masalah maka proses akan kembali ke tahap perancangan sistem.

Pada tahap analisa dilakukan berbagai uji coba pada program yang telah dilakukan untuk melakukan penyusunan laporan dari hasil uji coba dan analisa.

\subsection{Diagram Alir Sistem}

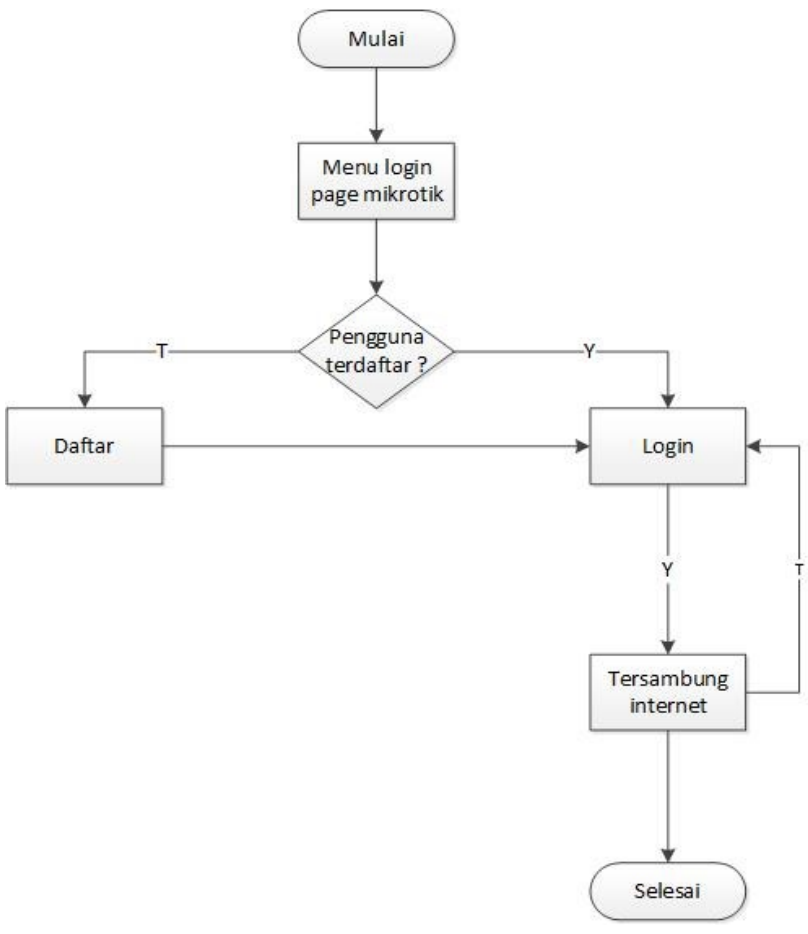

Gambar 2. Diagram Alir Sistem

Pada Gambar 2 merupakan diagram alir proses berjalannya sistem. Jika dilihat dari diagram tersebut user yang belum memiliki akses untuk masuk ke sistem maka user tersebut harus melakukan pendaftaran untuk MEMPEROLEH username dan password, apabila telah memiliki username dan password maka user hanya melakukan proses login saja. Jika user baru maka akan dilakukan proses pendaftaran. Proses pendaftaran akan dialihkan langsung ke sistem pendaftaran hotspot online.

Setelah user melakukan pendaftaran hotspot online berbasis web, maka user tersebut akan mendapatkan notifikasi berupa email. Dimana email yang diperoleh oleh user tersebut akan dikirimkan berupa username dan password untuk masuk kedalam jaringan internet pada sekolah ini.
Pada Gambar 3.merupakan rancangan topologi jaringan dan sistem yang akan dibuat pada tugas akhir ini. Pada Gambar 3 terdapat penambahan perangkat keras jaringan yaitu mikrotik RB750, Access Point, Server Radius user manager, Server database dan API. Fungsi mikrotik sebagai penghubung antara jaringan publik dengan jaringan lokal, fungsi Access Point sebagai penghubung jaringan tanpa kabel (nirekabel), Server radius user manager digunakan untuk menampung jumlah user yang terhubung dengan jaringan wifi dan server database dan API mikrotik digunakan untuk terhubung dengan database pendaftaran

\subsection{Rancangan Sistem yang Diusulkan}

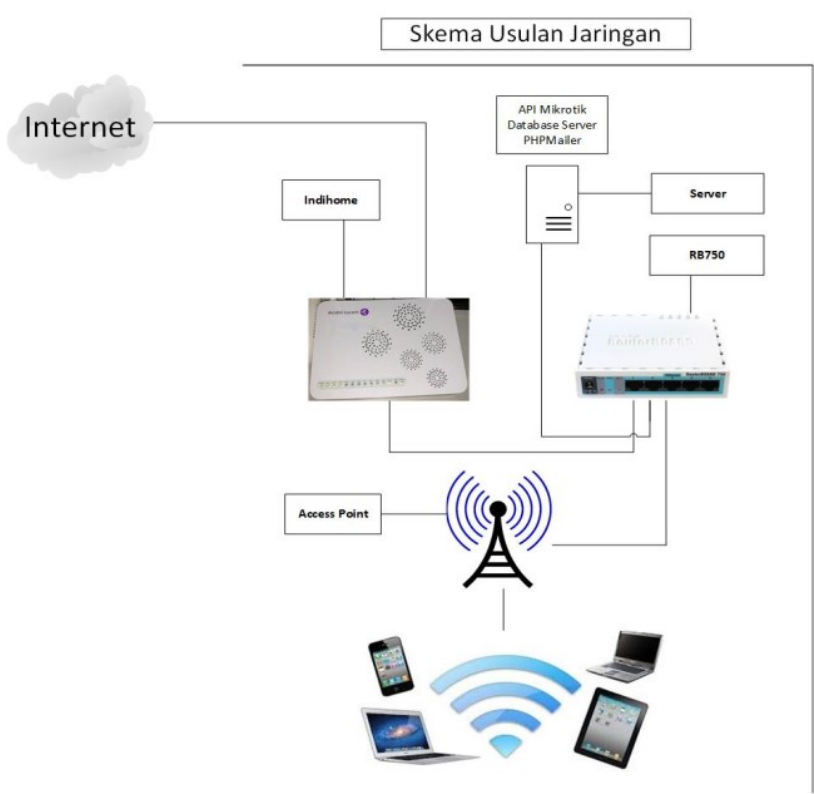

Gambar 3. Rancangan Sistem

\section{a.1 Use Case Diagram Admin dan Pengguna}

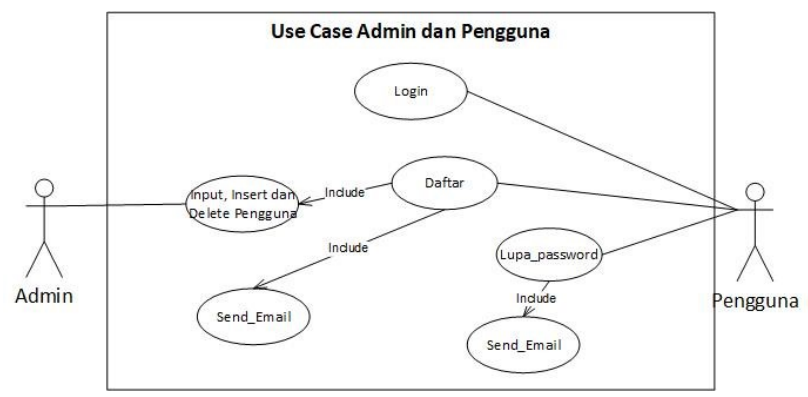

Gambar 4. Use Case Diagram Sistem Pendaftaran

Pada Gambar 4 alur jalannya sistem yang digambarkan dalam use case diagram, terdiri dari 2 aktor dan 5 use case. 


\section{Hasil dan Pembahasan}

\subsection{Implementasi Database}

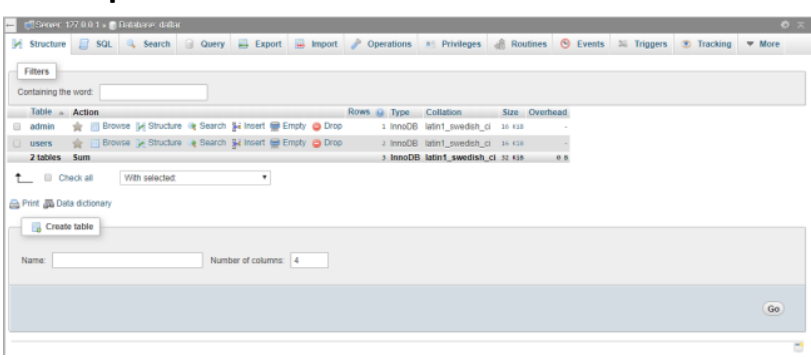

Gambar 5. Database daftar

Pada Gambar 5 adalah pembuatan database daftar. Pada database daftar tersebut terdapat dua tabel yaitu tabel admin dan users, tabel admin digunakan untuk menyimpan data-data admin untuk digunakan login kedalam sistem, sedangkan tabel users digunakan untuk menyimpan data pengguna yang akan menggunakan sistem pendaftaran layanan hotspot yang dibangun. Tabel admin dapat dilihat pada Gambar 6.

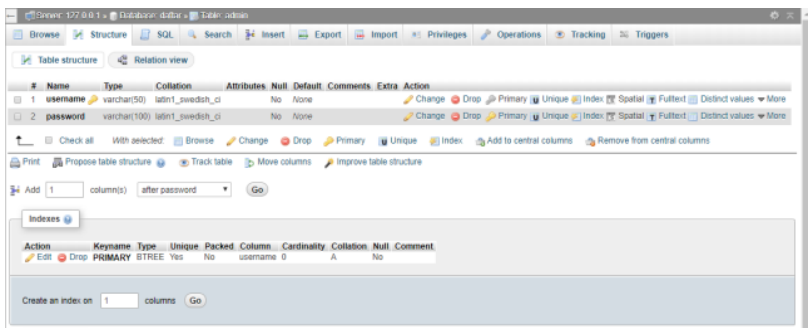

Gambar 6. Tabel admin

Pada Gambar 6 merupakan tabel admin yang digunakan untuk menyimpan data admin.

Pada tabel admin terdapat 2 field yaitu username dan password. Sedangkan tabel users dapat dilihat pada Gambar 7.

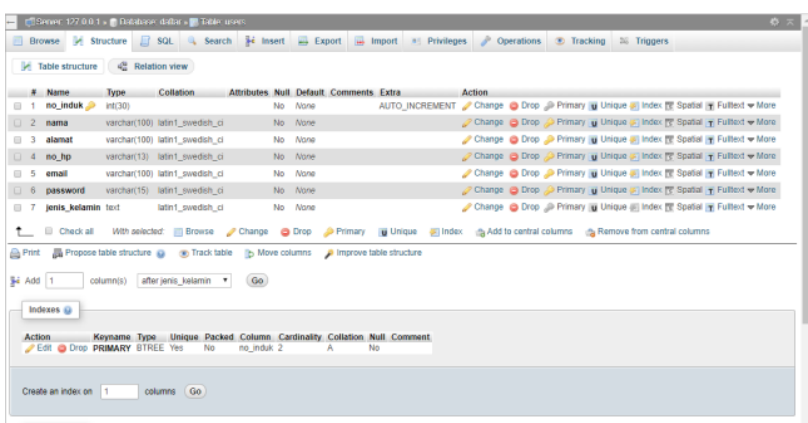

Gambar 7. Tabel users

Pada Gambar 7 merupakan Tabel users yang digunakan untuk menyimpan data pengguna yang sudah melakukan pendaftaran hotspot.

\subsection{Implementasi Halaman Login Admin}

Halaman login sistem admin merupakan halaman login bagi admin untuk mengakses sistem pendaftaran layanan hotspot dan pada halaman ini admin melakukan penambahan data pengguna. Halaman login admin dapat dilihat pada Gambar 8.

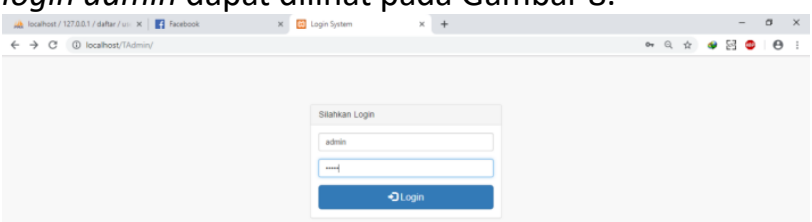

Gambar 8. Halaman Login Admin

\subsection{Implementasi Halaman Data Pengguna}

Halaman data pengguna dilakukan oleh admin setelah melakukan login ke dalam sistem, pada tahap ini admin melakukan entri no induk pengguna yang akan disimpan kedalam database. Setelah entri no induk pengguna maka pengguna dapat melakukan pendaftaran hotspot. Halaman data pengguna dapat dilihat pada Gambar 9.

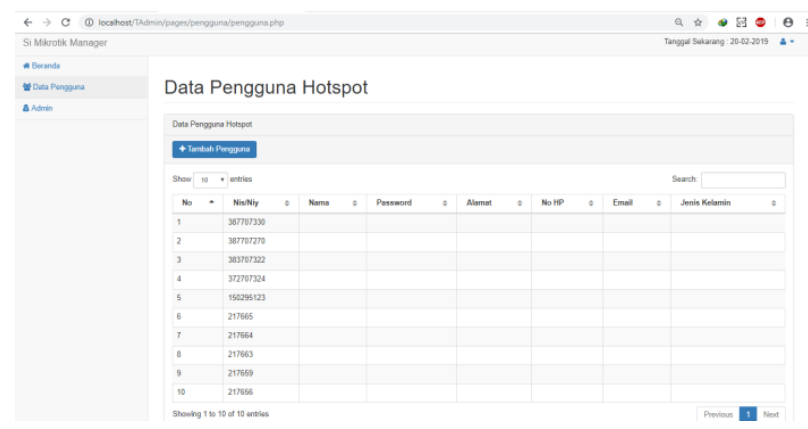

Gambar 9. Halaman Data Pengguna

Pada Gambar 9 merupakan tampilan halaman data pengguna yang sudah di entri no induk oleh admin.

\subsection{Implementasi Halaman Login Pengguna}

Halaman login hotspot merupakan tampilan dari login page mikrotik dimana pada halaman ini pengguna harus mengisi username dan password untuk memperoleh akses internet dari sistem ini. Halaman login pengguna dapat dilihat pada Gambar 8. Pada Gambar 10 merupakan tampilan login page hotspot mikrotik, pada tampilan ini pengguna diminta untuk memasukkan username dan password untuk 
mendapatkan koneksi internet dari sistem. Jika pengguna belum memiliki akun maka dilakukan proses daftar terlebih dahulu. Jika pengguna memiliki akun tetapi pengguna lupa password maka pengguna harus melakukan reset password dengan masuk kehalaman lupa password.

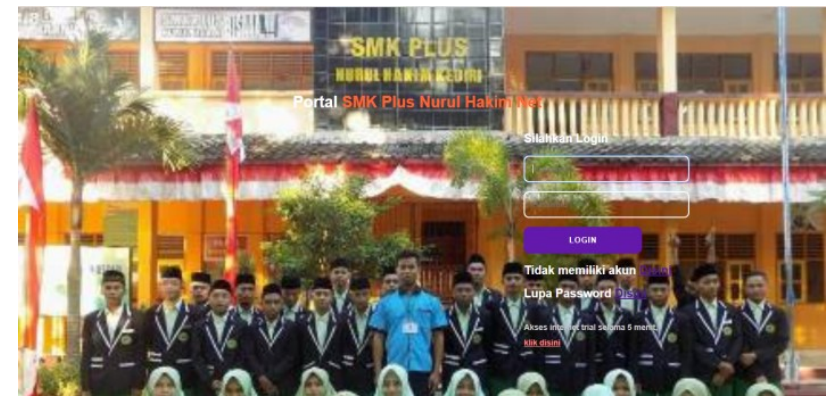

Gambar 10. Login page hotspot

Pada Gambar 10 merupakan tampilan login page hotspot mikrotik, pada tampilan ini pengguna diminta untuk memasukkan username dan password untuk mendapatkan koneksi internet dari sistem. Jika pengguna belum memiliki akun maka dilakukan proses daftar terlebih dahulu. Jika pengguna memiliki akun tetapi pengguna lupa password maka pengguna harus melakukan reset password dengan masuk kehalaman lupa password.

\subsection{Implementasi Halaman Daftar Pengguna}

Pada halaman pendaftaran pengguna hotspot ini pengguna akan melakukan pendaftaran akun untuk memperoleh username dan password yang digunakan untuk melakukan login kedalam hotspot. Halaman daftar pengguna dapat dilihat pada Gambar 8.

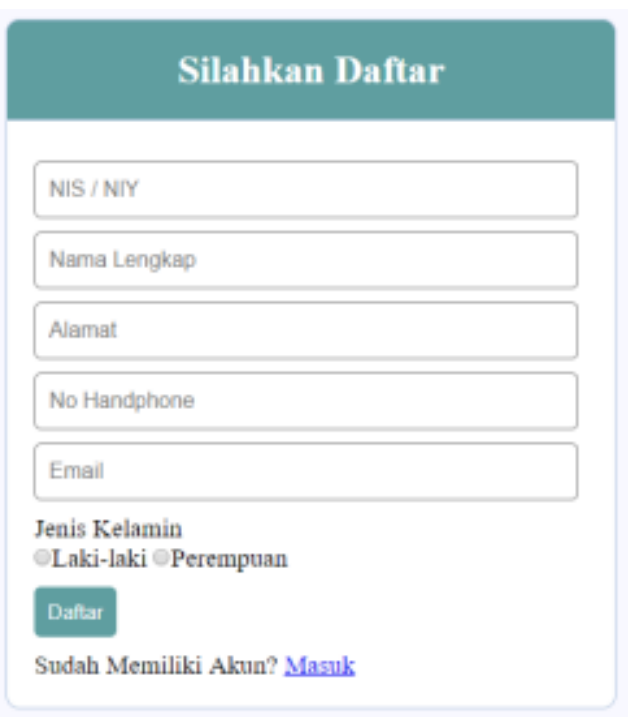

Gambar 11. Halaman daftar pengguna
Pada Gambar 11 pengguna melakukan proses pendaftaran untuk memperoleh username dan password yang digunakan untuk memperoleh akses internet. Pada Gambar 11 pengguna dibedakan berdasarkan no induk pengguna. Jika pengguna yang melakukan pendaftaran adalah siswa maka memiliki 6 digit no induk, sedangkan jika pengguna yang melakukan pendaftaran adalah guru maka memilik no induk 9 digit.

Setelah proses pendaftaran dilakukan sistem otomatis akan memilih pengguna berdasarkan no induk yang didaftarkan, kemudian sistem otomatis akan memberikan akses internet berdasarkan no induk yang didaftarkan.

\subsection{Implementasi Halaman Lupa Password}

Pada halaman lupa password pengguna dapat meminta password baru dengan mengisi halaman lupa password. Halaman lupa password dapat dilihat pada Gambar 12.

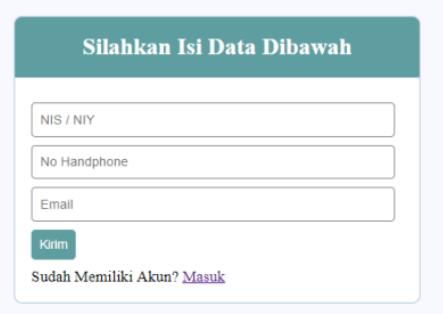

Gambar 12. Halaman lupa password

Pada Gambar 12 merupakan tampilan halaman lupa password, pada tahap ini pengguna diminta untuk memasukkan no induk dan email yang dimiliki harus sesuai pada saat melakukan proses pendaftaran, karna pada tahap ini sistem akan mengirimkan password baru kepada pengguna yang digunakan untuk melakukan proses login kembali.

\subsection{Pengujian Sistem}

Pada tahap pengujian Sistem Pendaftaran Pengguna Layanan Hotspot Berbasis Web Di SMK Plus Nurul Hakim Kediri menggunakan empat teknik pengujian yaitu black box, pengujian perhitungan Bandwidth, pengujian notifikasi sistem dan pengujian penggunaan user.

\subsubsection{Pengujian Black Box}

Metode pengujian black box merupakan metode pengujian yang menguji fungsi-fungsi di dalam sistem 
untuk menentukan apakah fungsi-fungsi tersebut sudah berjalan sesuai harapan atau tidak.

\section{A. Fungsi Login Admin}

Fungsi login admin dilakukan untuk menguji apakah fungsi yang berjalan pada halaman login admin sudah berjalan dengan baik dan benar. Funsi login admin dapat dilihat pada Tabel II.

\section{B. Fungsi Pendaftaran Pengguna}

Fungsi pendaftaran pengguna hotspot dilakukan untuk menguji apakah pengguna berhasil melakukan pendaftaran dengan baik dan benar.

\section{Fungsi lupa password}

Fungsi lupa password dilakukan untuk menguji apakah fungsi lupa password berjalan dengan baik dan benar.

\section{Fungsi entri no induk pengguna}

Fungsi entri no induk pengguna dilakukan untuk memasukkan no induk pengguna kedalam database, sehingga pada saat pengguna melakukan pendaftaran akun sistem bisa menerima pengguna tersebut untuk melakukan pendaftaran.

E. Funsi login pengguna

Fungsi login pengguna dilakukan bagi pengguna yang sudah melakukan proses pendaftaran akun, fungsi login pengguna dilakukan supaya pengguna bisa mendapatkan koneksi internet.

\subsubsection{Pengujian Perhitungan Bandwidth}

Pengujian hasil bandwidth dilakukan untuk menguji apakah hasil perolehan bandwidth yang didapat sudah sesuai dengan skala prioritas yang sudah ditentukan oleh sistem. Untuk bandwidt pengguna yang login dengan akun guru akan memperoleh kecepatan download/upload 512kbps sedangkan bagi pengguna yang login dengan akun siswa akan memperoleh kecepatan download/upload sebesar 256kbps. Untuk pengujian perolehan bandwidth dapat dilihat pada Tabel I.
TABEL I. PENGUIIAN BANDWIDTH

\begin{tabular}{|l|l|l|l|}
\hline \multicolumn{1}{|c|}{$\begin{array}{c}\text { Skenario } \\
\text { Pengujian }\end{array}$} & $\begin{array}{l}\text { Hasil yang } \\
\text { Diharapkan }\end{array}$ & $\begin{array}{c}\text { Hasil } \\
\text { Pengujian }\end{array}$ & Kesimpulan \\
\hline $\begin{array}{l}\text { Pengujian } \\
\text { pengguna } \\
\text { yang login } \\
\text { dengan } \\
\text { menggunakan } \\
\text { akun siswa } \\
\text { yang berhasil } \\
\text { login }\end{array}$ & $\begin{array}{l}\text { Proses } \\
\text { perolehan } \\
\text { bandwidth } \\
\text { unlimited } \\
\text { kan } \\
\text { internet } \\
\text { 256kbps }\end{array}$ & Valid \\
\hline $\begin{array}{l}\text { Pengujian } \\
\text { pengguna } \\
\text { yang login } \\
\text { dengan } \\
\text { menggunakan } \\
\text { akun guru } \\
\text { yang berhasil } \\
\text { login }\end{array}$ & $\begin{array}{l}\text { Proses } \\
\text { perolehan } \\
\text { bandwidth } \\
\text { unlimited } \\
\text { kecepan } \\
\text { internet } \\
\text { 512kbps }\end{array}$ & Sesuai & \\
& & \\
\end{tabular}

Pada Tabel I merupakan tabel pengujian perolehan bandwidt yang diperoleh oleh pengguna, pengguna yang masuk dengan akun guru akan memperoleh bandwidth unlimited dengan kecepatan upload/download sebesar 512kbps. Sedangkan jika pengguna masuk menggunakan akun siswa maka akan memperoleh bandwidth unlimited dengan kecepatan akses internet sebesar $256 \mathrm{Kbps}$. Dari hasil perolehan bandwidth yang diperoleh dengan menggunakan akun guru dapat dilihat pada Gambar 13. Sedangkan perolehan bandwidth yang diperoleh dengan menggunakan akun siswa dapat dilihar pada Gambar 14.

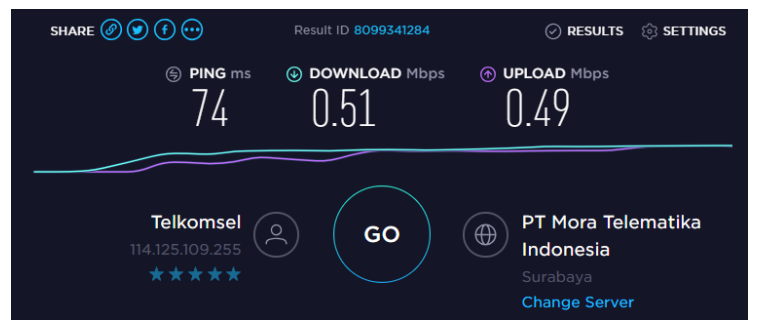

Gambar 13. Uji kecepatan internet guru

Pada Gambar 13 menunjukkan bahwa pengguna yang masuk menggunakan akun guru akan mendapatkan kecepatan internet 700Kbps untuk download dan 400 Kbps untuk upload sehingga membutikkan bahwa pengguna dengan akun guru sudah mendapatkan limitasi kecepatan dari kecepatan internet sebenarnya. Pada Gambar 14 menunjukkan bahwa pengguna yang masuk menggunakan akun 
siswa akan mendapatkan kecepatan internet $500 \mathrm{Kbps}$ untuk download dan 200Kbps untuk upload sehingga membutikkan bahwa pengguna dengan akun siswa sudah mendapatkan limitasi kecepatan lebih lambat daripada akun guru dari kecepatan internet sebenarnya.

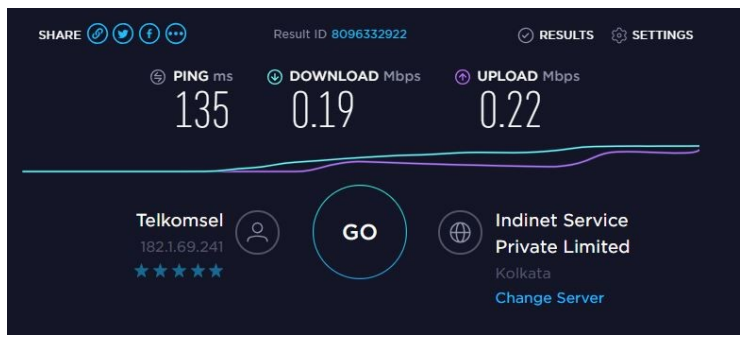

Gambar 14 Uji kecepatan koneksi internet siswa

Pengujian bandwidth ini dilakukan setelah adanya limitasi dari sistem. Pada jaringan hotspot sekolah SMK Plus Nurul Hakim Kediri ini memiliki bandwidth asli sebesar Up To 20Mbps, kecepatan dari bandwidth yang didapatkan dari jaringan ini dapat dilihat pada Gambar 15.

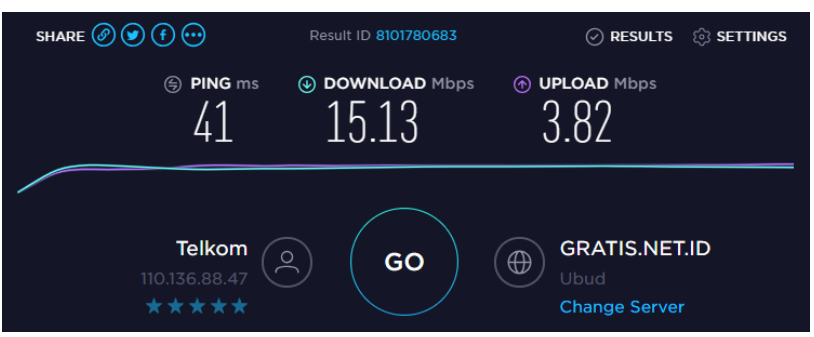

Gambar 15. Pengujian Bandwidth sebenarnya

\subsubsection{Pengujian Halaman Trial}

Pada tahap pengujian halaman trial ini dilakukan untuk mengakses internet secara gratis selama 5 menit. Pengguna mengakses internet melalui halaman trial untuk membuka email, karena sistem ini akan mengirimkan notifikasi username dan password melalui email. Untuk mengakses halaman trial hotspot dapat dilihat pada Gambar 10.

\subsubsection{Pengujian notifikasi sistem}

Pengujian notifikasi sistem dilakukan untuk memperoleh username dan password bagi pengguna yang melakukan proses daftar pada sistem. Jika pengguna telah melakukan pendaftaran meggunakan email yang aktif maka notifikasi berupa username dan password akan dikirim secara otomatis lewat email yang terdaftar di sistem. Notifikasi email dapat dilihat pada Gambar 15.

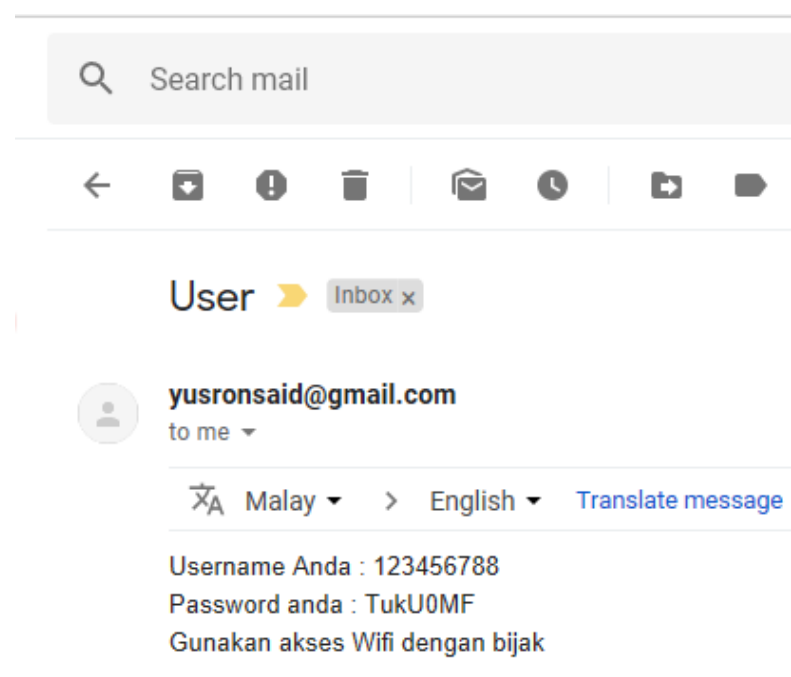

Gambar 15. Notifikasi email

Pada Gambar 15 merupakan tampilan notifikasi username dan password yang dikirimkan oleh sistem secara otomatis setelah pengguna melakukan pendaftaran. Pada sistem ini pengiriman email dilakukan dengan bantuan PHP Mailer.

\subsubsection{Pengujian kuesioner}

Pengujian dengan menggunakan kuesioner dilakukan dengan mencari responden untuk mencoba menjalankan sistem, lalu memberikan pertanyaan berupa kuesioner. Tujuan dari penelitian ini adalah untuk mengetahui bagaimana kualitas sistem dilihat dari sisi pengguna.

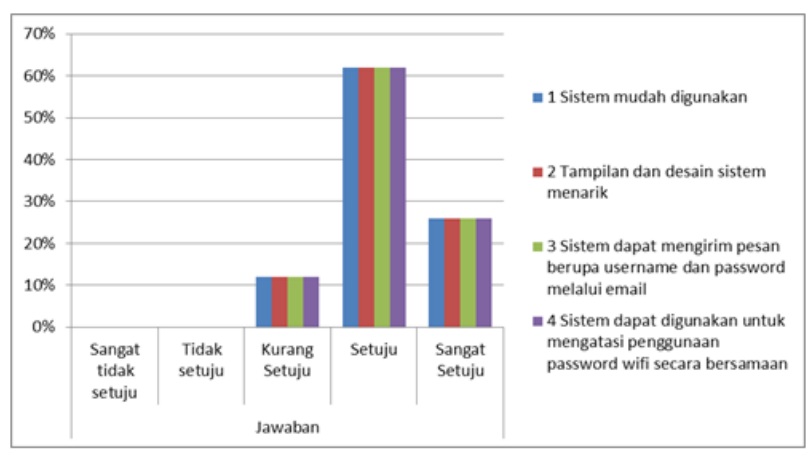

Gambar 16. Grafik Persentase Rata-rata Jawaban Responden

Kuesioner pada sistem ini ada dua yaitu kuesioner pengguna dan admin, kuesioner pengguna disebar kepada 20 orang pengguna dan kuesioner admin 1, kuesioner ini terdiri dari empat pertanyaan dengan menggunakan lima jawaban pilihan yang mewakili dari tujuan akhir yang ingin tercapai dalam pembangunan sistem. 
Berdasarkan Gambar 16 dapat disimpulkan bahwa sebesar $62.68 \%$ responden pengguna sistem sudah menarik dari aspek tampilan, mudah digunakan, dapat memperoleh notifikasi username dan password, dan dapat mengatasi masalah penggunaan password wifi secara bersamaan di sekolah ini.

\section{KeSimpUlan dan SARAN}

\subsection{Kesimpulan}

Kesimpulan yang didapat dalam penyusunan tugas akhir ini adalah :

1. Pendaftaran pengguna dapat dilakukan secara mandiri melalui sistem pendaftaran hotspot.

2. Management bandwidth dengan memanfaatkan sistem API Mikrotik.

3. Sistem ini dapat mengirimkan notifikasi username dan password melalui email.

4. Dari hasil pengujian yang dilakukan sudah sesuai dengan permasalahan yang ada pada sekolah SMK Plus Nurul Hakim kediri.

5. Berdasarkan kuesioner yang diberikan kepada 20 pengguna menyatakan bahwa 62\% responden pengguna sistem sudah setuju bahwa sistem ini menarik dari aspek tampilan, mudah digunakan, dapat memperoleh notifikasi username dan password, dan dapat mengatasi masalah penggunaan password secara bersamaan di wifi di sekolah ini.

6. Berdasarkan kuesioner yang diberikan kepada admin menyatakan setuju bahwa sistem ini mudah digunakan, menarik dari aspek tampilan, sistem ini membantu mengatasi pergantian password secara rutin, dan sistem ini dapat digunakan untuk mengatur beban bandwidth wifi di sekolah ini.

\subsection{Saran}

Dalam pembuatan sistem ini penulis merasakan banyak sekali kekurangan, oleh karna itu masukan dan saran yang sifatnya membangun yang perlu penulis harapkan sehingga harapannya sistem ini kedepannya jauh lebih bagus dengan banyak fitur tambahan seperti :

1. Support dengan mikrotik yang tidak memiliki usermanager.

2. Support pengiriman notifikasi username dan password lewat SMS.
3. Support edit,delete dan tambah user

\section{DAFTAR PUSTAKA}

[1] P. C. S. Teknologi, "Artikel Bandwidth Management untuk Dynamic User," 209AD. [Online]. Available: http://www.mikrotik.co.id/artikel_lihat.php?id=98.

[2] Mikrotik, "Manual Application Programmable Interface," 2019. [Online]. Available: https://wiki.mikrotik.com/wiki/Manual:API.

[3] Oracle Corporation Affiliates, "Chapter 1. General Information," Flow Resistance, 2017. [Online]. Available:

https://dev.mysql.com/doc/refman/8.0/en/introdu ction.html.

[4] Z. Musliyana, "Sistem Pendaftaran Hotspot Berbasis Web pada Hotspot Mikrotik Stimik U'Budiyah Menggunakan Mikrotik Application Programing Interfaces ( API ), PHP, dan MySQL," Pros. SNIKOM, no. January, pp. 1-10, 2014.

[5] M. M. A. Ghoni, "Perancangan Manajemen User Pada Hotspot Menggunakan Mikrotik," Universitas Muhammadiyah Surakarta, 2013.

[6] B. Hermawan, "Perancangan Jaringan Hotspot Server Berbasis Mikrotik di Gedung Kuliah Universitas Abulyatama," STMIK U'BUDIYAH INDONESIA, 2013.

[7] P. Ilmiah, N. Hidayat, P. S. Informatika, F. Komunikasi, D. A. N. Informatika, and U. M. Surakarta, "Perancangan dan Implementasi Jaringan Hotspot untuk Akses Internet di SMK Asta Mitra Purwodadi," Perancanagan Dan Implementasi, no. Perancanagan Dan Implementasi, pp. 1-20, 2016.

[8] M. Gelar, S. Teknik, P. Studi, T. Informatika, and T. B. Santoso, "Menggunakan Php. Sistem Administrasi Otentikasi Hotspot Berbasis Web Web Based Authentication Hotspot Administration System," 2007.

[9] A. Wicahyanto and E. W. Sumirat, "Pendaftaran pengguna layanan hotspot berbasis web Pada hotspot mikrotik dan freeradius," Pendaftaran pengguna layanan hotspot Berbas. web, vol. 1, no. November, pp. 46-55, 2012.

[10] F. H. Samsul Arifin, Zainal Arifin, "Integrasi Layanan Hotspot Dengan Data Akademik Pada Sekolah Tinggi Teknologi Nurul Jadid," vol. 8, pp. 294-300, 2016. 